\title{
Time to Listen: Children's Voice in Geoscience Education Research
}

\author{
Emer Emily Neenan, Joseph Roche* and Laura Bell \\ Trinity College Dublin, Dublin, Ireland
}

Arguably the greatest threat facing society is that posed by irreversible climate change. In tandem with mitigating the effects of climate change, we must now make decisions about issues such as renewable energy, sustainable and safe water supplies, management of renewable and non-renewable natural resources, and management of natural disasters. The current school-age generation will see the worst effects of climate change, including greater frequency and intensity of extreme weather events; shortages of water and other necessary resources; and dangers due to pollution and toxicity in human environments and the human food chain. The next generation is coming of age as difficult socio-political choices are being made at local and national levels to manage resources and mitigate environmental damage. It is therefore important to center the voices of children and young people in research aiming to address the social, political, and educational dimensions of geoscience topics, including climate change and related topics. This paper proposes the

OPEN ACCESS

Edited by:

Fátima Alves,

Universidade Aberta, Portugal

Reviewed by:

Ana M. Bijóias Mendonça, University of Coimbra, Portugal

Sheila Holz,

University of Coimbra, Portugal

*Correspondence:

Joseph Roche

Joseph.Roche@tcd.ie

Specialty section:

This article was submitted to

Science and Environmental

Communication,

a section of the journal

Frontiers in Environmental Science

Received: 18 February 2021 Accepted: 06 May 2021

Published: 21 May 2021

Citation:

Neenan EE, Roche $J$ and Bell L (2021) Time to Listen: Children's Voice in Geoscience Education Research.

Front. Environ. Sci. 9:669430. doi: 10.3389/fenvs.2021.669430 use of Children's Research Advisory Groups (CRAGs) to meaningfully include children and young people as co-researchers in geoscience-related research.

Keywords: climate education, children's research advisory group, student voice, science communication, public engagement, climate change, science and society

\section{INTRODUCTION: WHY LISTEN TO CHILDREN ABOUT GEOSCIENCE}

Climate change is a vast, accelerating, and highly complex threat to human civilisation on our planet, requiring both scientific and socio-political expertise to tackle (Grundmann, 2016). Global warming is likely to reach $1.5^{\circ} \mathrm{C}$ between 2030 and 2052 if it continues to increase at the current rate, leading to natural disasters, low harvests, biodiversity loss, etc, according to the UN Intergovernmental Panel on Climate Change (IPCC). These effects, already in motion, are expected to worsen over the coming years, with a well-publicised estimation in 2018 by the IPCC that we had fewer than 12 years to make the significant changes required to tackle this threat (now 10 years) (Intergovernmental Panel on Climate Change, 2018).

Therefore, significant decisions being taken today and over the next few years-on regulations, investments, and management strategies-will determine the state of the world the current cohort of school students inherit as young adults. It is the next generation that will bear the worst of the effects of unmanaged climate change, yet the decisions that determine how well those effects will be avoided or managed are being taken before the current generation of school students can vote or directly influence policy. These students have indeed been making their voices heard via protests, social media activism, and school strikes. It is vitally important to listen to them, and center the voices of children and young people in research aiming to address the social, political, and educational dimensions of climate change and related topics. 


\section{Youth Activism}

It would be of benefit to both the young people and the researchers for researchers on climate change to listen to the younger generation.

Young people have been a force in environmental activism for a long time, although attention has generally focused more on young adults (particularly college students) than on minors. The first "Earth Day" in 1970 was marked by activism on college campuses (Freeman III, 2002; Rome, 2010). Individual youth activist activity during the 1990's and early 2000's led to the formation of the Youth Climate Movement in 2005 (Ogrodnik and Staggenborg, 2016; Foran et al., 2017). Compared with older generations, young people are consistently "associated with activism and with liberal politics” (Harris, 2017) (p. 296). It makes sense that younger people are more likely to challenge a conservative status quo than their parents and grandparents, who are perhaps more likely to be comfortably established within it (Flanagan and Tucker, 1999; Sloam, 2013).

It also makes sense that young people are more likely to be concerned with projections of climate devastation over the coming decades than older people who may not live long enough to see the worst effects. Wray-Lake, Flanagan, and Osgood (Wray-Lake et al., 2010) write that "today's young people will inevitably become national and global leaders with responsibility for environmental stewardship and sustainability" (p. 62).

In August 2018, teenage climate activist Greta Thunberg staged a protest outside the Swedish Riksdag (parliament), with a sign that read "Skolstrejk för klimatet" ("School strike for the climate"). She has since staged the same protest every Friday (www.fridaysforfuture.org), and has been joined by both individual strikers and mass protests in countries from Ireland to Japan to Argentina (Taylor, 2019). Reis, Ng-A-Fook, and Glithero (Reis et al., 2015) provide a table of examples of "youth who are leading the way in recent environmental action" (p. 44).

Children and young people are increasingly aware that on the current trajectory, the risks and dangers of climate change will be significantly worse by the time they come of age.

\section{The Case for Children's Voice in Geoscience Research}

Thus the intertwined issues of climate change, sustainability, pollution, etc, are of considerable importance to the next generation (Fisher, 2016). But when research is undertaken, it is conceived, designed, and enacted by adults. The lives of children and teenagers have changed drastically since current adult researchers were teenagers (Sandeen, 2008). How can adults know if they're even asking the right questions, if they have little familiarity with the world teenagers are living in now? Furthermore, teenagers and young people use language differently to older people; not just unfamiliar new slang, but pioneering new grammatical constructions (McCulloch, 2019). If they manage to ask the right questions, how can they be sure they're interpreting the answers accurately?

The United Nations Convention on the Rights of the Child (UNCRC) says that children should have meaningful input on issues that affect them. This must include research undertaken on these issues, particularly where the goal of the research is to inform policy.

Research undertaken that will directly or indirectly affect the lives of young people should be informed by the experiential expertise of young people themselves. The following section will explain one method of centering children's voice by including representative students as co-researchers during the research process (Broström, 2012).

\section{HOW TO LISTEN TO CHILDREN ABOUT GEOSCIENCE}

James (James, 2007) catalogs the ways in which children's voices can be used in research, along with the common problems and pitfalls: "Giving voice to children is not simply or only about letting children speak; it is about exploring the unique contribution to our understanding of and theorizing about the social world that children's perspectives can provide" (p. 262).

In order to incorporate children's and young people's voices in matters that affect them, it is useful to follow the principles laid out in the UNCRC. Giving children the opportunity to speak is not enough; there are four elements that must be present for their voice to be meaningfully incorporated. These are: Space, that is, the opportunity and time to express their views; Voice, including ensuring they have the requisite vocabulary; Audience, meaning that someone will listen to their views; and Influence, or the potential to actually enact change or progress (Lundy, 2007). The last of the four elements is crucial there is no point listening to, e.g., student climate activists, if their opinions and preferences will not have an effect on the decisions being taken on policy (Welty and Lundy, 2013). While efforts have been made to involve children in problematising climate change (Arts, 2019), expanding the focus to geoscience more broadly would provide young people with a deeper understanding of the myriad factors affecting their future.

\section{The Research Advisory Group}

The Children's Research Advisory Groups (CRAGs) method centers children's or students' voice in research (Lundy et al., 2011; Murphy et al., 2013). Representative groups of children act as expert co-researchers, giving their opinions derived from their experiential expertise on "children similar to themselves" (for example, their peers, classmates, siblings, etc). This method was first described by Lundy and McEvoy (Lundy and McEvoy, 2009), then called a Children's Advisory Group.

As Lundy and McEvoy (ibid) describe, school is likely to be the most convenient location to hold a CRAG, however, it's important that the students don't feel like the CRAG is "schoolwork" or that they have to participate, or have to provide a "right answer". In order to minimise this, CRAGs are conducted in a manner that isn't like ordinary school, and the young co-researchers are consulted or given control over many aspects of the CRAG. For example, Lundy and McEvoy (ibid) suggest the CRAG not take place in the students' usual classroom (preferably in an unconventional room such as the art room) and proceedings kept informal. Young co-researchers choose their own system for pseudonyms, if pseudonyms will be used. 


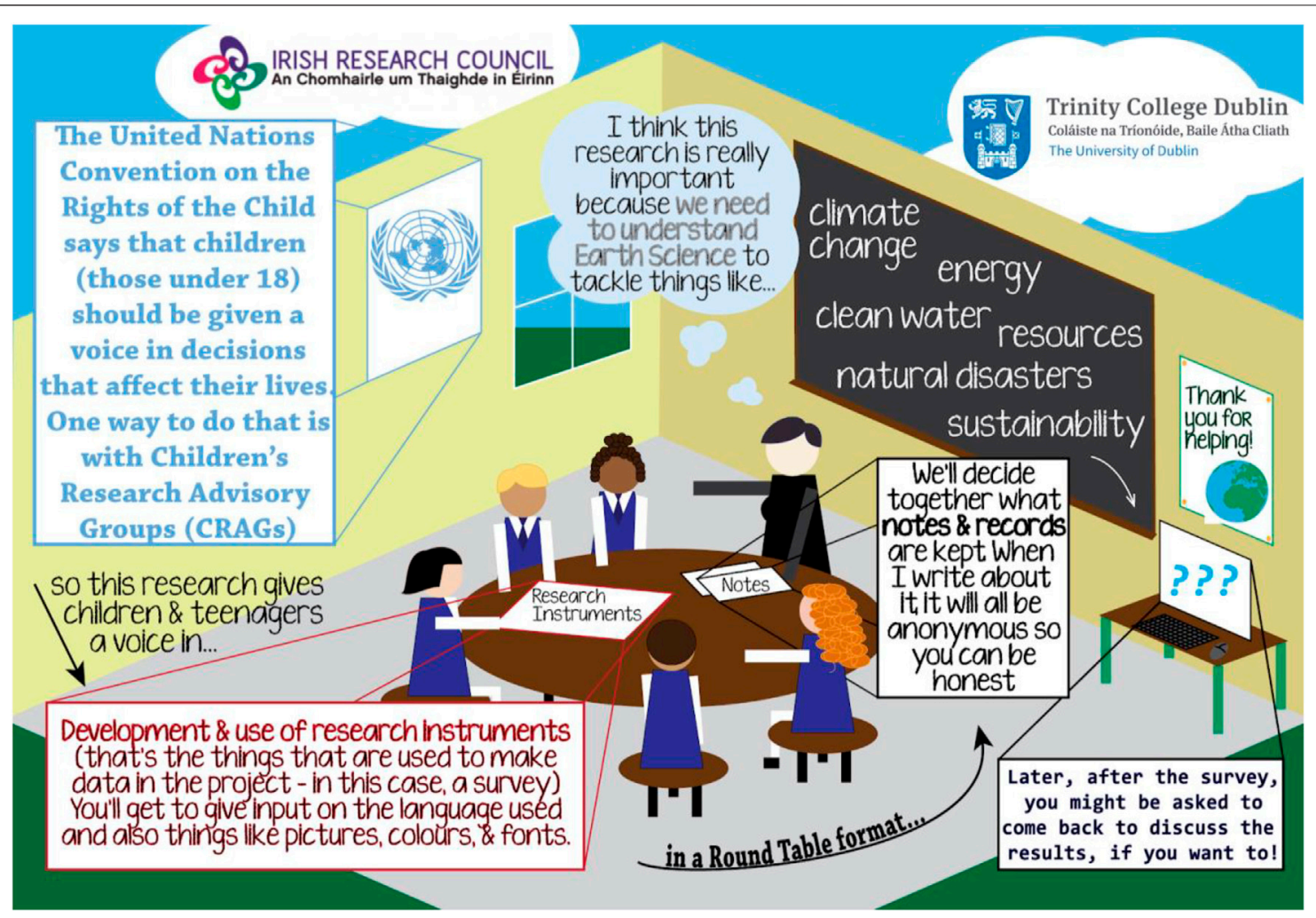

FIGURE 1 | Children's Research Advisory Groups: An excerpt (edited for clarity) from the information sheet given to student co-researchers as part of an ongoing geoscience education research project undertaken by the authors (Artist is EN).

Perhaps most importantly, young co-researchers jointly determine how the CRAGs proceed, how the discussion is framed, and how records are kept. As can be seen in Figure 1, the Research Advisory Group method is particularly useful for topics where there is a high degree of student engagement, as is the case with climate change and environmental issues. Although multifaceted and multidimensional in their nature, these problems can be tackled by the advisory groups through longer or repeated engagements. As well as helping them to express their views, capacity-building activities can aid children in familiarising themselves with issues they may not have encountered before and applying the views they form to situations other than their own experiences [ibid]. To make such a process feasible, a CRAG facilitator visiting a school needs the support and backing of both school and teacher.

\section{DISCUSSION}

\section{Let Students Improve Geoscience Education}

There is a need to address the place of geoscience in formal education (Lewis and Baker, 2010; Neenan and Roche, 2016). Children's lives are framed around school from as young as four years old until typically their late teens. It is unsurprising that the teenage-driven climate change protest has focused on school strikes. Students ask why they should go to school if they are not being prepared for climate change, and instead are being taught skills and knowledge that may not be useful in a rapidly changing world.

Placards with slogans such as "Why bother with school when you won't listen to the educated?" and "This generation got no destination" are brandished by frustrated school students (Figure 2).

Student activist groups in several countries have explicitly called for climate change to be addressed in schools. For example, the Irish student-led activist group Schools' Climate Action Network Ireland has called for "reform of the education system to address the need for ecological literacy" (O'Sullivan and Kelleher, 2019) In many countries, climate change, natural resources, natural disasters, and sustainability are touched on as part of subjects such as Science, Geography, and Social Science, but there are increasing calls globally for climate change to be covered in more depth and detail in the formal education system. A YouGov poll commissioned by Oxfam in the United Kingdom found that $69 \%$ of teachers agreed there should be more emphasis on climate change in schools, but that three-quarters of teachers did not feel they had received adequate training to be able to deliver climate change content in lessons. This research didn't address students' opinions, nor is students' knowledge of the system usually drawn upon in curriculum reform.

One theory of the purpose of formal education is to prepare children for the future. It is increasingly clear that the impacts of climate change will significantly affect current students' futures, 


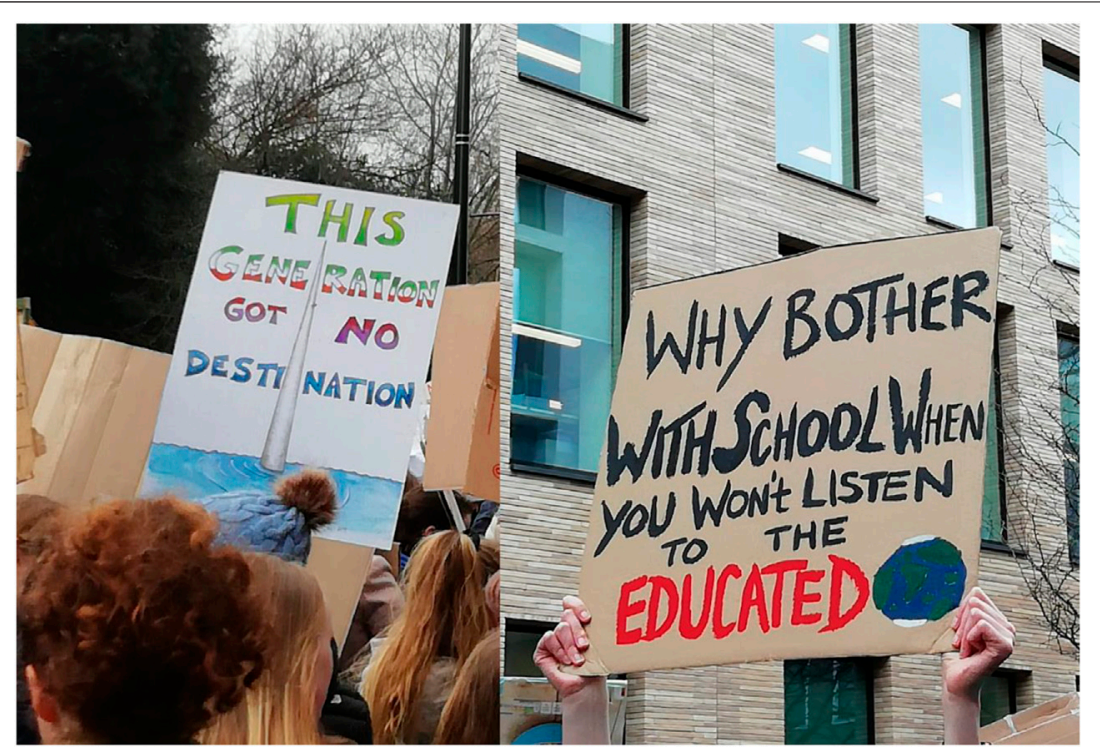

FIGURE 2 | In Their Own Words: Signs by students expressing frustration at the first major School Strike For Climate march in Ireland, on Friday the March 15, 2019 (Photographer is EN).

and the formal education system must take this into account. Using CRAGs in education research is relatively time-consuming and requires a lot of work from the school(s) as well as from the researcher(s). However, it is potentially an invaluable tool for education reform at all levels.

\section{Let Underrepresented Groups Improve Inclusion and Access}

The geosciences in Western countries have long been dominated by white men, at the loss of the expertise and perspectives of women, people of other races and ethnicities, disabled people, queer people, etc. (Holmes et al., 2008; Atchison and MartinezFrias, 2012; Bernard and Cooperdock, 2018). Matters are improving, particularly with regard to gender, but slowly, and success with diversity and inclusion programs has been mixed (Dobbin and Kalev, 2016; Huntoon, 2016). Research on barriers and obstacles to inclusion, and programs and initiatives to diversify a field, are most effective when underrepresented groups have input from the very beginning (Abu-Amsha et al., 2019; Young et al., 2019). In order to attract and retain more female, Black or minority ethnic, disabled, queer, working class, and other underrepresented geoscientists tomorrow, involve children and teenagers in the research on diversity and inclusion today.

\section{CONCLUSION: BY LISTENING TO CHILDREN AND YOUNG PEOPLE, WE GIVE THEM POWER}

Given the recent trends towards greater participant-driven research, crowdsourcing, and citizen science, it is important to make visible and clear the full context of how power is being returned to the participants in a system (Woolley and et al., 2016; Roche et al., 2020). Even aside from ethical or moral considerations of returning power to participants in research, children and young people have expertise on their own experience, which can be leveraged to improve data collection and analysis. With enough qualitative and quantitative data collection, the Research Advisory Group method could inform policy recommendations. In the context of geoscience education, this could lead to children's input being explicitly integrated into formal education systems, while the underlying CRAG method could be readily adapted to different disciplines and educational contexts.

In order to balance the power in a researcher-participant interaction, care must be taken at every stage of the process. Eitzel et al. (Eitzel et al., 2017) show that even the terminology itself should be chosen carefully, and its usage explained for all participants. Aspects such as the language used or the space in which the discussion takes place must be considered and, if necessary, reworked. This is a process that costs time and effort, but that results in better data, and data that is arguably generated more ethically.

“Honoring young children's rights to express their views creates more effective policy and it fosters stronger, more cohesive and inclusive communities. In these ways it contributes to a healthy democracy which recognises that children's rights are the human rights of any citizen" (MacNaughton et al., 2007) (p. 9).

"Those who will be affected the hardest are already suffering the consequences. But their voices are not heard" (Thunberg, 2019). 
This doesn't just apply to young people: it applies to coastal and island villages, subsistence farmers, Indigenous populations, and many others. But the further someone is from their life expectancy, the greater the threat of climate change. Young people must be given a seat at the table when the future of the planet 10, 20, 30 years from now is being discussed ( $O$ 'Brien and Political agency, 2015).

Students are experts on their own experiences and the realities of the worlds they live in; classrooms, family homes, family farms, student activist circles, clubs and sports, their local area. That expertise can and should be tapped into, especially when the stakes for the planet have never been higher.

\section{DATA AVAILABILITY STATEMENT}

The raw data supporting the conclusion of this article will be made available by the authors, without undue reservation.

\section{ETHICS STATEMENT}

The studies involving human participants were reviewed and approved by the Trinity College Dublin Research Ethics

\section{REFERENCES}

Abu-Amsha, O., Gordon, R., Benton, L., Vasalou, M., and Webster, B. (2019). Access to Higher Education: Reflections on a Participatory Design Process with Refugees. Jeie 5 (1), 156-176. doi:10.33682/tm40-9q50

Arts, K. (2019). "Children's Rights and Climate Change," in Children's Rights and Sustainable Development: Interpreting the UNCRC for Future Generations. Editor C. Fenton-Glynn (Cambridge, United Kingdom: Cambridge University Press), 216-235. doi:10.1017/9781108140348.010

Atchison, C., and Martinez-Frias, J. (2012). Inclusive Geoscience Instruction. Nat. Geosci. 5, 366. doi:10.1038/ngeo1487

Bernard, R. E., and Cooperdock, E. H. G. (2018). No Progress on Diversity in 40 Years. Nat. Geosci. 11 (5), 292-295. doi:10.1038/s41561-018-0116-6

Broström, S. (2012). Children's Participation in Research. Int. J. Early Years Edu. 20 (3), 257-269. doi:10.1080/09669760.2012.715407

Dobbin, F., and Kalev, A. (2016). Why Diversity Programs Fail. Harv. Business Rev. 52-60. Available at: http://go.nature.com/2egFwUt July-August, 2016).

Eitzel, M. V., Cappadonna, J. L., Santos-Lang, C., Duerr, R. E., Virapongse, A., West, S. E., et al. (2017). Citizen Science Terminology Matters: Exploring Key Terms. Cstp 2 (1), 1-20. doi:10.5334/cstp. 96

Fisher, S. R. (2016). Life Trajectories of Youth Committing to Climate Activism. Environ. Edu. Res. 22 (2), 229-247. doi:10.1080/13504622. 2015.1007337

Flanagan, C. A., and Tucker, C. J. (1999). Adolescents' Explanations for Political Issues: Concordance with Their Views of Self and Society. Dev. Psychol. 35 (5), 1198-1209. doi:10.1037/0012-1649.35.5.1198

Foran, J., Gray, S., and Grosse, C. (2017). Not yet the End of the World: Political Cultures of Opposition and Creation in the Global Youth Climate justice Movement. Interface 9, 353-379.

Freeman, A. M., III (2002). Environmental Policy since Earth Day I: what Have We Gained?. J. Econ. Perspect. 16 (1), 125-146. doi:10.1257/0895330027148

Grundmann, R. (2016). Climate Change as a Wicked Social Problem. Nat. Geosci. 9 (8), 562-563. doi:10.1038/ngeo2780

Harris, A. (2017). "Young People, Politics and Citizenship," in Handbook of Youth and Young Adulthood: New Perspectives and Agendas. Editor A. Furlong Second edition (New York, NY: Taylor \& Francis).
Committee. Written informed consent to participate in this study was provided by the participants' legal guardian/next of kin.

\section{AUTHOR CONTRIBUTIONS}

EN carried out the CRAGs and led the writing of the paper. JR and LB contributed to the conceptual design, writing, and editing.

\section{FUNDING}

This work was made possible through generous support from Geological Survey Ireland and the Irish Research Council through their Government of Ireland Postgraduate Scholarship and COALESCE programmes.

\section{ACKNOWLEDGMENTS}

The authors are grateful for the support of Geological Survey Ireland and the Irish Center for Research in Applied Geosciences. Particular thanks to Barry Neenan, MLIS, for his assistance in his capacity as librarian.

Holmes, M. A., O’Connell, S., Frey, C., and Ongley, L. (2008). Gender Imbalance in US Geoscience Academia. Nat. Geosci. 1 (2), 79-82. doi:10.1038/ngeo113 Huntoon, J. E. (2016). Of Rocks and Social justice. Nat. Geosci. 9 (11), 797. Intergovernmental Panel on Climate Change (2018). World Meteorological Organisation/United Nations Environment Programme. Clim. Change IPCC Scientific Assess. Retrieved from: https://www.ipcc.ch/site/assets/uploads/2018/ 03/ipcc_far_wg_I_full_report.pdf.

James, A. (2007). Giving Voice to Children's Voices: Practices and Problems, Pitfalls and Potentials. Am. Anthropologist 109 (2), 261-272. doi:10.1525/aa. 2007.109.2.261

Lewis, E. B., and Baker, D. R. (2010). A Call for a New Geoscience Education Research Agenda. J. Res. Sci. Teach. Official J. Natl. Assoc. Res. Sci. Teach. 47 (2), $121-129$.

Lundy, L. (2007). 'Voice' Is Not Enough: Conceptualising Article 12 of the United Nations Convention on the Rights of the Child. Br. Educ. Res. J. 33 (6), 927-942. doi:10.1080/01411920701657033

Lundy, L., McEvoy, L., and Byrne, B. (2011). Working with Young Children as Coresearchers: an Approach Informed by the United Nations Convention on the Rights of the Child. Early Edu. Dev. 22 (5), 714-736. doi:10.1080/10409289. 2011.596463

Lundy, L., and McEvoy, L. (2009). Developing Outcomes for Educational Services: a Children's Rights-based Approach. Eff. Edu. 1 (1), 43-60. doi:10.1080/ 19415530903044050

MacNaughton, G., Hughes, P., and Smith, K. (2007). Young Children's Rights and Public Policy: Practices and Possibilities for Citizenship in the Early Years. Child. Soc. 21 (6), 458-469. doi:10.1111/j.1099-0860.2007.00096.x

McCulloch, G. (2019). Because Internet: Understanding How Language Is Changing. London: Harvill Secker.

Murphy, C., Lundy, L., Emerson, L., and Kerr, K. (2013). Children's Perceptions of Primary Science Assessment in England and Wales. Br. Educ. Res. J. 39 (3), 585-606. doi:10.1080/01411926.2012.674921

Neenan, E. E., and Roche, J. (2016). Geoscience Education in an Irish Context: a Need for Research. Gep 04 (6), 1-8. doi:10.4236/gep.2016.46001

O'Brien, K., and Political agency, K. (2015). Political agency: The Key to Tackling Climate Change. Science 350 (6265), 1170-1171. doi:10.1126/science.aad0267

Ogrodnik, C., and Staggenborg, S. (2016). The Ebb and Flow of Environmentalism. Sociol. Compass 10 (3), 218-229. doi:10.1111/soc4.12353 
O'Sullivan, K., and Kelleher, O. (2019). The Irish Times. Retrieved from: https://www. irishtimes.com/news/environment/student-protest-calls-on-government-to-takeradical-action-on-climate-crisis-1.3903414.

Reis, G., Ng-A-Fook, N., and Glithero, L. (2015). "Provoking Ecojustice - Taking Citizen Science and Youth Activism beyond the School Curriculum," in EcoJustice, Citizen Science and Youth Activism: Environmental Discourses in Science Education. Editors M. Mueller and D. Tippins (Dordrecht: Springer).

Roche, J., Bell, L., Galvão, C., Golumbic, Y. N., Kloetzer, L., Knoben, N., et al. (2020). Citizen Science, Education, and Learning: Challenges and Opportunities. Front. Sociol. 5 (613814), 1-10. doi:10.3389/fsoc.2020.613814

Rome, A. (2010). The Genius of Earth Day. Environ. Hist. 15 (2), 194-205. doi:10. 1093/envhis/emq036

Sandeen, C. Boomers. (2008). Xers, and Millennials: Who Are They and what Do They Really Want from Continuing Higher Education?. Cont. Higher Edu. Rev. $72,11-31$

Sloam, J. (2013). 'Voice and Equality': Young People's Politics in the European Union. West Eur. Polit. 36 (4), 836-858. doi:10.1080/01402382.2012.749652

Taylor, M. (2019). The Guardian. Retrieved from: https://www.theguardian.com/ environment/2019/may/24/schoolchildren-go-on-strike-across-world-overclimate-crisis.

Thunberg, G. (2019). No One Is Too Small to Make A Difference. London: Penguin UK.
Welty, E., and Lundy, L. (2013). A Children's Rights-Based Approach to Involving Children in Decision Making. Jcom 12 (3), C02. doi:10.22323/2.12030302

Woolley, J. P., et al. (2016). Citizen Science or Scientific Citizenship? Disentangling the Uses of Public Engagement Rhetoric in National Research Initiatives. BMC Med. Ethics 17, 33. doi:10.1186/s12910-016-0117-1

Wray-Lake, L., Flanagan, C. A., and Osgood, D. W. (2010). Examining Trends in Adolescent Environmental Attitudes, Beliefs, and Behaviors across Three Decades. Environ. Behav. 42 (1), 61-85. doi:10.1177/0013916509335163

Young, M., Magassa, L., and Friedman, B. (2019). Toward Inclusive Tech Policy Design: a Method for Underrepresented Voices to Strengthen Tech Policy Documents. Ethics Inf. Technol. 21 (2), 89-103. doi:10.1007/s10676-019-09497-z

Conflict of Interest: The authors declare that the research was conducted in the absence of any commercial or financial relationships that could be construed as a potential conflict of interest.

Copyright (c) 2021 Neenan, Roche and Bell. This is an open-access article distributed under the terms of the Creative Commons Attribution License (CC BY). The use, distribution or reproduction in other forums is permitted, provided the original author(s) and the copyright owner(s) are credited and that the original publication in this journal is cited, in accordance with accepted academic practice. No use, distribution or reproduction is permitted which does not comply with these terms. 